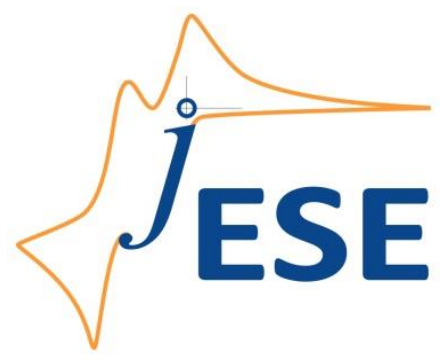

Open Access : : ISSN 1847-9286

www.jESE-online.org

Original scientific paper

\title{
Electrocoagulation removal of anthraquinone dye Alizarin Red $S$ from aqueous solution using aluminum electrodes: kinetics, isothermal and thermodynamics studies
}

\author{
Abideen Idowu Adeogun*,**, ${ }^{*}$, Ramesh Babu Balakrishnan** \\ *Department of Chemistry, Federal University of Agriculture, Abeokuta, Nigeria \\ **Electrochemical Pollution Control Division, CSIR - Central Electrochemical Research Institute. \\ Karaikudi 630006, India
}

${ }^{\boxplus}$ Corresponding Author: abuaisha2k3@yahoo.com, Tel: +23480306126987 and +918098772434

Received: May 3, 2016; Revised: May 22, 2016; Accepted: May 23, 2016

\begin{abstract}
Electrocoagulation (EC) was used for the removal of anthraquinone dye, Alizarin Red $S$ (ARS) from aqueous solution. The process was carried out in a batch electrochemical cell with Al electrodes in a monopolar connection. The effects of some important parameters such as current density, $\mathrm{pH}$, temperature and initial dye concentration, on the process were investigated. Equilibrium was attained after 10 minutes at $30^{\circ} \mathrm{C}$. Pseudo-first order, pseudo-second order, Elovic, and Avrami kinetic models were used to test the experimental data in order to elucidate the kinetics of the electrocoagulation process; pseudo-first order and Avrami models best fitted the data. Experimental data were analyzed using six isotherm models: Langmuir, Freudlinch, Redlich-Peterson, Temkin, Dubinin-Radushkevich and Sips isotherms and it was found that the data fitted well with Dubinin-Radushkevich and Sips isotherm model. The study showed that the process depended on the current density, temperature, $\mathrm{pH}$ and initial dye concentration. The calculated thermodynamics parameters $\left(\Delta \mathrm{G}^{\circ}, \Delta \mathrm{H}^{\circ}\right.$ and $\left.\Delta \mathrm{S}^{\circ}\right)$ indicated that the process is spontaneous and endothermic in nature.
\end{abstract}

\section{Keywords}

Batch; Electrochemical cell; Mnopolar connection; Pseudo first order; Equilibrium; Spontaneous.

\section{Introduction}

The advanced in technologies for industrialization and urbanization has substantially enhanced the degradation of the environment especially the aquatic environment, through the discharge of industrial wastewaters and domestic wastes [1,2]. The residual dyes from different sources such 
as: textile, paper and pulp, dye and dye intermediates, pharmaceutical, tannery, and kraft bleaching industries are considered as organic coloured pollutants [3-6]. These industries utilize large quantities of a number of dyes with residues leading to the large amount of coloured wastewaters, toxic and even carcinogenic, posing serious hazard to aquatic living organisms. Most dyes used in industries are stable to light, heat and oxidation, they are not biologically degradable and are also resistant to aerobic digestion and even when they does, they produce toxic and hazardous products $[7,8]$.

Anthraquinone dye Alizarin Red $S$ (ARS) is available as sodium salt of 1,2-dihydroxy-9,10-anthraquinonesulfonic acid (Fig. 1) and it is referred to as Mordant Red 3, C.I. no. 58005. Alizarin, a natural dye obtained from madder (Rubiatinctorum, L. Rubiaceae) by sulphonation, is a watersoluble and widely used anthraquinone dye in textile and as a stain in clinical study of synovial fluid to assess basic calcium phosphate crystals [9]. ARS is a durable pollutant when released to aquatic ecosystems. It cannot be completely degraded by general physicochemical and biological processes because of the complex structures of the aromatic rings that afford high physicochemical, thermal, and optical stability $[7,10]$. Therefore, most treatments for such dye-laden effluents are largely inadequate; however, removal of this dye from industrial wastewaters is a crucial process, from both economic and environmental points of view [11].

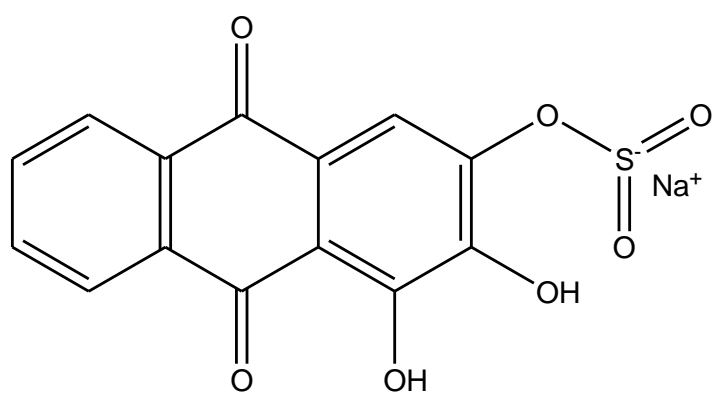

Figure 1. Structure of Alizarin Red S (ARS)

Electrochemical techniques which include electrooxidation, electrochemical reduction, electrocoagulation, electroflotation [12], have been developed for the treatment of organic pollutants in waste water with higher efficiency than any other biological, physical and chemical process $[13,15]$. Electrocoagulation has been known for some time as a process capable of fractionating a number of organic substances in a rather efficient manner. The coagulants are generated in-situ by electrooxidation of the anode. The mostly used anode materials are iron and aluminum because of their availability and relatively low cost. Electrocoagulation is accomplished in a three step processes as follows: (i) electrolytic reactions at surface of electrodes, (ii) formation of coagulants in aqueous phase and (iii) adsorption of soluble or colloidal pollutants onto coagulants and removal of them using sedimentation or flotation of flocs when hydrogen gas bubbles were produced at the cathode [16].

Several methods have been used for the removal of ARS from wastewaters, these include adsorption [17-19], electrochemical degradation [20-23] and electro-Fenton process [24] using various electrodes. However, to the best of our knowledge, kinetics and isothermal studies have not been elucidated in any of these studies.

In this study, ARS was removed from aqueous solution in a mono-polar electrochemical cell using aluminum electrodes. The effect of current density, initial dye concentration, electrolyte concentration, $\mathrm{pH}$ and temperature were studied. Adsorption kinetics of electrocoagulants was analyzed with pseudo-first order, pseudo-second order, Elovic, and Avrami kinetic models. The 
diffusion mechanism was analyzed with intraparticulate diffusion model while the equilibrium adsorption behaviour was analyzed by fitting the equilibrium data with six isotherm models. Thermodynamic parameters such as free energy $(\Delta G)$, enthalpy $(\Delta H)$ and entropy $(\Delta S)$ were also determined to understand the spontaneity of the electrocoagulation process.

The following reactions were envisaged at the electrodes:

Anodic reaction:

$\mathrm{Al} \rightarrow \mathrm{Al}^{3+}+2 \mathrm{e}^{-}$

Cathodic reaction:

$3 \mathrm{H}_{2} \mathrm{O}+3 \mathrm{e}^{-} \rightarrow 3 \mathrm{OH}-+3 / 2 \mathrm{H}_{2} 3 \mathrm{H}_{2} \mathrm{O}$

Overall reaction:

$\mathrm{Al}^{3+}+3 \mathrm{OH}^{-} \rightarrow \mathrm{Al}(\mathrm{OH})_{3}$

\section{Experimental}

\section{Dye solution preparation}

Alizarin Red S (sodium alizarin sulphonate (Fig. 1), Cl 58005, Product No. - 13005) was a product of British Drug House, Poole, England. $1000 \mathrm{mg} \mathrm{L}^{-1}$ aqueous solution of ARS was prepared with de-ionized water as the stock solution and was further diluted with de-ionized water to obtain the working standard solutions. The $\mathrm{pH}$ of the solution was adjusted when necessary with aliquots of $1.0 \mathrm{~mol} \mathrm{~L}^{-1}$ of $\mathrm{HCl}$ and $\mathrm{NaOH}$ before the commencement of the experiment. The conductivity of the solution was maintained with $\mathrm{NaCl}$ solution as the electrolyte.

\section{Experimental apparatus and procedures}

Figure 2 depicts the electrocoagulation cell which consists of a $0.6 \mathrm{~L}$ glass cell fitted with a polycarbonate cell cover with slots to introduce the electrodes, thermometer and electrolyte. The aluminum electrodes of dimensions $4.5 \times 7 \times 0.3 \mathrm{~cm}$ with inter electrode distance of $2 \mathrm{~cm}$ were fully immersed in the $0.5 \mathrm{~L}$ solution of the dye. A regulated direct current (DC) was supplied from a rectifier (0-2 A, 0-35 V; Applab 7711 multi-output). The temperature of the electrolyte was controlled to the desired value with a variation of $\pm 1{ }^{\circ} \mathrm{C}$ by adjusting the temperature knob on the IKA RCT Basic magnetic hotplate stirrer and was allowed to equilibritate before the commencement of the experiment.

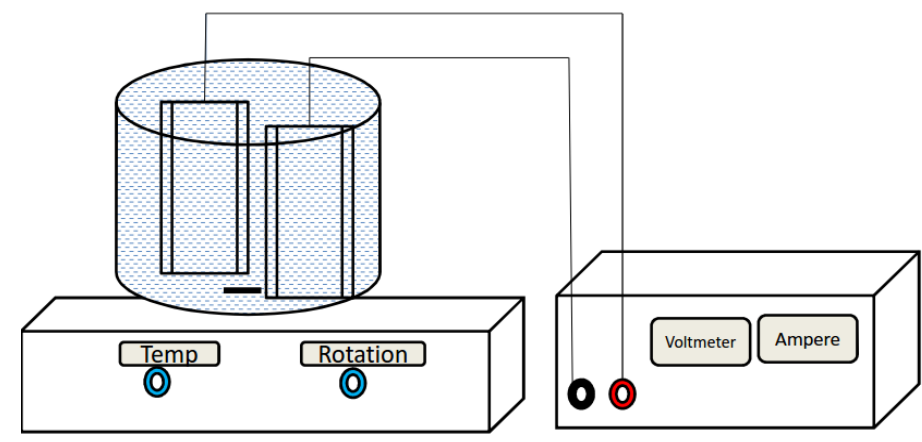

Figure 2. Laboratory scale electrocoagulation cell

\section{Analytical procedure}

The concentration of the dye in solution was estimated using spectrophotometer (UV-VIS -NIR VARIAN 500 Scan CARY). To compare the dye obtained from the coagulation with the original ARS 
dye, the flock is filtered and the residue dried at $105{ }^{\circ} \mathrm{C}$ for 30 minutes, then the FTIR of the two samples (ARS and residue) were obtained using FTIR spectrophotometer (TENSOR 27 Bruker Optik $\mathrm{GmbH}$, Germany). Non-linear regression analysis method using a program written on Micro Math Scientist software (Salt Lake City, Utah) was used to obtain the least square fit for all the models.

\section{Equilibrium studies}

The effects of current density, initial dye concentration, electrolyte concentration, $\mathrm{pH}$ and temperature on the electrocoagulation removal of ARS were studied. Sample solutions were withdrawn at intervals to determine the residual dye concentration by using UV-VIS-NIR spectrophotometer. The amount of dye coagulated at equilibrium, $Q_{\mathrm{e}} / \mathrm{mg} \mathrm{g}^{-1}$, was calculated using equation 4 below:

$$
Q_{\mathrm{e}}=\frac{\left(C_{\mathrm{o}}-C_{\mathrm{e}}\right) V}{W}
$$

where $C_{\mathrm{o}} / \mathrm{mg} \mathrm{L}^{-1}$ is the initial concentration and $C_{\mathrm{e}} / \mathrm{mg} \mathrm{L}^{-1}$ is the concentration of the dye at equilibrium in the liquid-phase. $V$ is the volume of the solution, $L$ while $W$ is the mass of the coagulant which can be estimated from Faraday Law according to the equation 5 :

$$
W=\frac{M l t}{n F}
$$

$M$ is the molar mass $\left(\mathrm{g} \mathrm{mol}^{-1}\right.$ ) of the elements, $l$ is the current $(\mathrm{A}), t$ is the electrocoagulation time in seconds, $n$ is the number of electrons involved and $\mathrm{F}$ is Faraday's constant $\left(96,485 \mathrm{C} \mathrm{mol}^{-1}\right)$.

The percentage dye removal as colour was estimated by:

$$
\text { Colour removal, } \%=\frac{\left(A b s_{0}-A b s_{\mathrm{e}}\right)}{A b s_{0}} \times 100
$$

where $A b s_{0}$, is the blank absorbance and $A b s_{\mathrm{e}}$ is the absorbance at equilibrium.

\section{Adsorption isotherms}

The equilibrium data from this study were described with the six adsorption isotherm models. These are models by Langmuir [25], Freudlinch [26], Temkin [27], Dubinin and Radushkevich [28], Sip [29] and Redlich and Peterson [30]. The acceptability and suitability of the isotherm equation to the equilibrium data were based on the values of the correlation coefficients, $R^{2}$ estimated from linear regression of the least square fit statistic on Micro Math Scientist software.

\section{Electrocoagulation kinetics studies}

Since the amount of coagulant can be estimated for a given time, the pollutant removal can be modelled using an adsorption phenomenon. The procedures for the kinetics studies were basically identical to those of equilibrium tests. The aqueous samples were taken at preset time intervals, and the concentrations of the dye were similarly determined. The amount of dye removed at time $t, Q_{t}\left(\mathrm{mg} \mathrm{g}^{-1}\right)$, was calculated using Equation 7:

$$
Q_{t}=\frac{\left(C_{\mathrm{o}}-C_{\mathrm{t}}\right) V}{W}
$$

where $C_{\mathrm{o}} / \mathrm{mg} \mathrm{L}^{-1}$ is the initial concentration and $C_{\mathrm{t}} / \mathrm{mg} \mathrm{L}^{-1}$ is the concentration of the dye at time $t$ in the liquid-phase. $V$ is the volume of the solution $(\mathrm{L})$, and $W$ is the mass of $\mathrm{Al}(\mathrm{OH})_{3}$ calculated as stated in eqn. 5 above. In order to investigate the mechanisms of the adsorption process, pseudo- 
first order, pseudo-second order, Avrami, and Elovich models respectively were applied to describe the kinetics of adsorption of ARS to $\mathrm{Al}(\mathrm{OH})_{3}$ generated during the electrocoagulation process. Since the diffusion mechanism cannot be obtained from the kinetic model, the intraparticulate diffusion model [8] was also tested. A model is adjudged best-fit and selected based on statistical parameters.

\section{Statistical test for the kinetics data}

The acceptability and hence the best fit of the kinetic data were based on the square of the correlation coefficients $R^{2}$ and the percentage error function which measures the differences (SSE, \%) in the amount of the dye concentration coagulated at equilibrium predicted by the models, $\left(Q_{\text {cal }}\right)$ and the actual, (i.e. $\left.Q_{\text {exp }}\right)$ measured experimentally. The validity of each model was determined by the sum of error squares (SSE, \%) given by:

$$
\mathrm{SSE}, \%=\sqrt{\frac{\left(\left(Q_{\exp }-Q_{\text {cal }}\right) / Q_{\exp }\right)^{2}}{N-1}} \times 100
$$

$N$ is the number of data points. The higher is the value of $R^{2}$ and the lower the value of SSE; the better fitted the data.

\section{Thermodynamics of electrocoagulation process}

Arrhenius equation is applied to estimate the activation energy of adsorption according to the relationship:

$$
\ln k=\ln A-\frac{E_{\mathrm{a}}}{R T}
$$

where $k$ is the rate constant obtained from the kinetic model, $E_{\mathrm{a}}$ is the Arrhenius activation energy of adsorption, $(\mathrm{kJ} / \mathrm{mol}), A$ is the Arrhenius factor, $R$ is the universal gas constant $\left(8.314 \mathrm{~J} \mathrm{~mol}^{-1} \mathrm{~K}^{-1}\right.$ ) and $T$ is the absolute temperature. The thermodynamics parameters i.e. $\Delta G^{\circ}, \Delta H^{\circ}$ and $\Delta S^{\circ}$ were estimated using the following relation:

$$
\begin{aligned}
& \Delta G^{\circ}=-R T \ln K_{\mathrm{d}} \\
& \ln K_{\mathrm{d}}=\frac{\Delta S^{\circ}}{R}-\frac{\Delta H^{\circ}}{R T}
\end{aligned}
$$

The equilibrium constant, $K_{\mathrm{d}}$, is obtained from the value of $Q_{\mathrm{e}} / C_{\mathrm{e}}$ at different temperature equilibrium study. Van't Hoff plot of In $K_{d}$ against the reciprocal of temperature $(1 / T)$, should give a straight line with intercept as $\Delta S_{\mathrm{o}} / R$ and slope as $\Delta H_{\mathrm{o}} / R$.

\section{Results and discussion}

\section{Batch equilibrium studies}

Effect of current density

The amount of coagulants generated is related to the time and current density [31]. Current density determines the coagulant production rate, and adjusts the rate and size of the bubble production, and hence affects the growth of flocs [32,33]. The effect current density on the removal of ARS, were carried at the current density varied between $j$ of 7.15 to $35.77 \mathrm{~A} \mathrm{~m}^{-2}$. Figure 3 shows the plot of current density versus the percentage colour removal by the 
electrocoagulation process. From the figure it is glaring that as the current density is increased the rate of colour removal also increased from 96 to $99.31 \%$. Increasing current density results in a corresponding increase in the production of coagulant in the solution leading to high efficiency. The optimum current density of $35.77 \mathrm{~A} \mathrm{~m}^{-2}$ was used throughout the study.

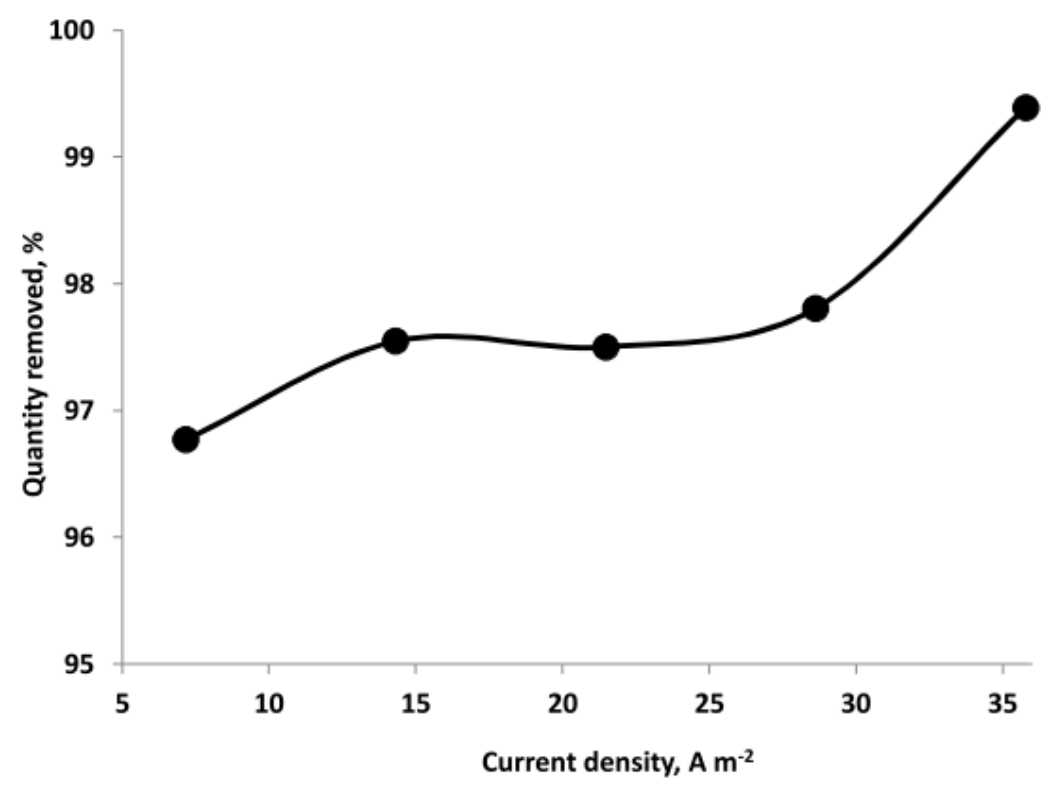

Figure 3. Effect of current density on colour removal $\left([\right.$ ARS $]=50 \mathrm{mg} \mathrm{L}^{-1}, \mathrm{~T}=30^{\circ} \mathrm{C}, \mathrm{pH} 7.0$ and $\left.[\mathrm{NaCl}]=2 \mathrm{gL}^{-1}\right)$.

\section{Effect of $\mathrm{pH}$ on electrocoagulation process}

$\mathrm{pH}$ is an important parameter influencing the performance of the EC process [34], it affects the chemistry of both the coagulants, dye molecules and that of electrochemical process in the solution. The effect $\mathrm{pH}$ on the removal of ARS was studied at initial $\mathrm{pH}$ varied between 3 and 11 . The $\mathrm{pH}$ was adjusted with $0.1 \mathrm{M} \mathrm{NaOH}$ or $0.1 \mathrm{M} \mathrm{HCl}$. The color removal percentages for dye solutions with various initial $\mathrm{pH}$ values were shown in Fig. 4.

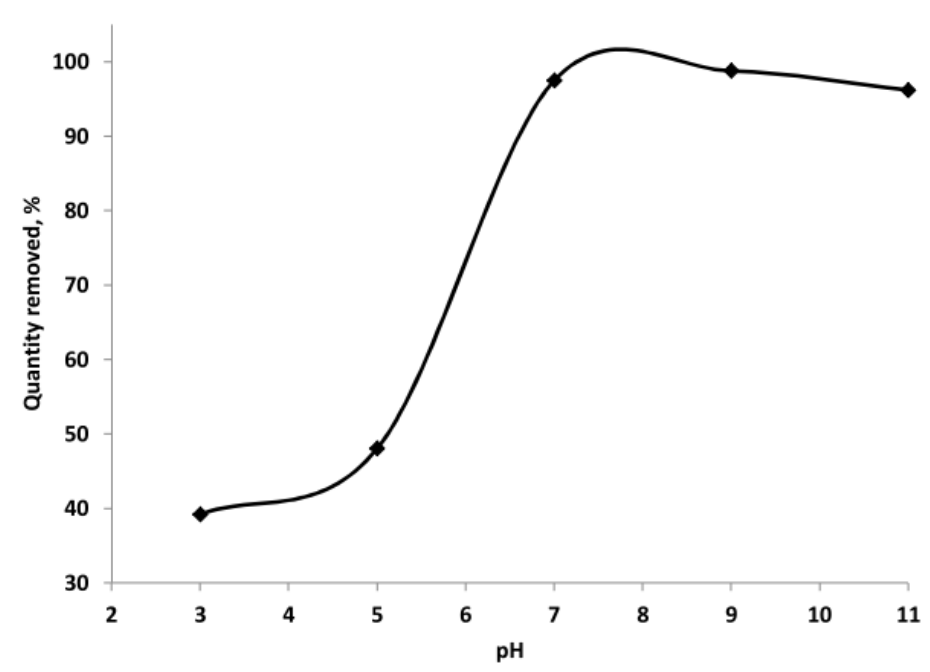

Figure 4. Effect of initial $\mathrm{pH}$ on colour removal

$$
\left([\mathrm{ARS}]=50 \mathrm{mg} \mathrm{L}^{-1}, \mathrm{~T}=30^{\circ} \mathrm{C},[\mathrm{NaCl}]=2 \mathrm{~g} \mathrm{~L}^{-1}, j=21.5 \mathrm{~A} \mathrm{~m}^{-2}\right)
$$

The colour removal efficiency are optimum at the at $\mathrm{pH}$ range of 6.5 and 7.5 with about $97.5 \%$ colour removal. The decrease in removal efficiency at more acidic and alkaline $\mathrm{pH}$ had been attributed to amphoteric behaviour of $\mathrm{Al}(\mathrm{OH})_{3}$ which leads to soluble $\mathrm{Al}^{3+}$ cations (at acidic $\mathrm{pH}$ ) and 
formation of monomeric anions (at alkaline $\mathrm{pH}$ ). These ions transform finally into solid $\mathrm{Al}(\mathrm{OH})_{3}$ according to complex precipitation kinetics thereby affecting the removal efficiency $[35,36]$.

\section{Effect of electrolyte concentration}

Solution conductivity influences the current efficiency, cell voltage and consumption of electrical energy in electrolytic cells. The use of $\mathrm{NaCl}$ to increase solution conductivity is also accompanied by the production of chloride ions that reduces the effects of other anions, such as bicarbonate and sulphate which may lead to the precipitation of $\mathrm{Ca}^{2+}$ leading to the high ohmic resistance of the electrochemical cell [17]. The tests of electrolyte concentration effects were performed in solutions containing a constant concentration of ARS $50 \mathrm{mg} \mathrm{L}^{-1}$, at current density of 21.5 $\mathrm{A} \mathrm{m}^{-2}$ and $\mathrm{pH} \mathrm{7,} \mathrm{while} \mathrm{the} \mathrm{concentrations} \mathrm{of} \mathrm{NaCl}$ were varied between 1 to $5 \mathrm{~g} \mathrm{~L}^{-1}$. Figure 5 shows that colour removal efficiency percentage increases from 86 to $97.6 \%$ as the electrolyte concentration rises up to $2 \mathrm{~g} \mathrm{~L}^{-1}$. A further increase in electrolyte concentrations beyond these values does not significantly affect the removal efficiency of the dye from the solution. The results also suggest that high colour removal percentage with low cell voltages and low energy consumption can be obtained at $\mathrm{NaCl}$ concentration of $2 \mathrm{~g} \mathrm{~L}^{-1}$.

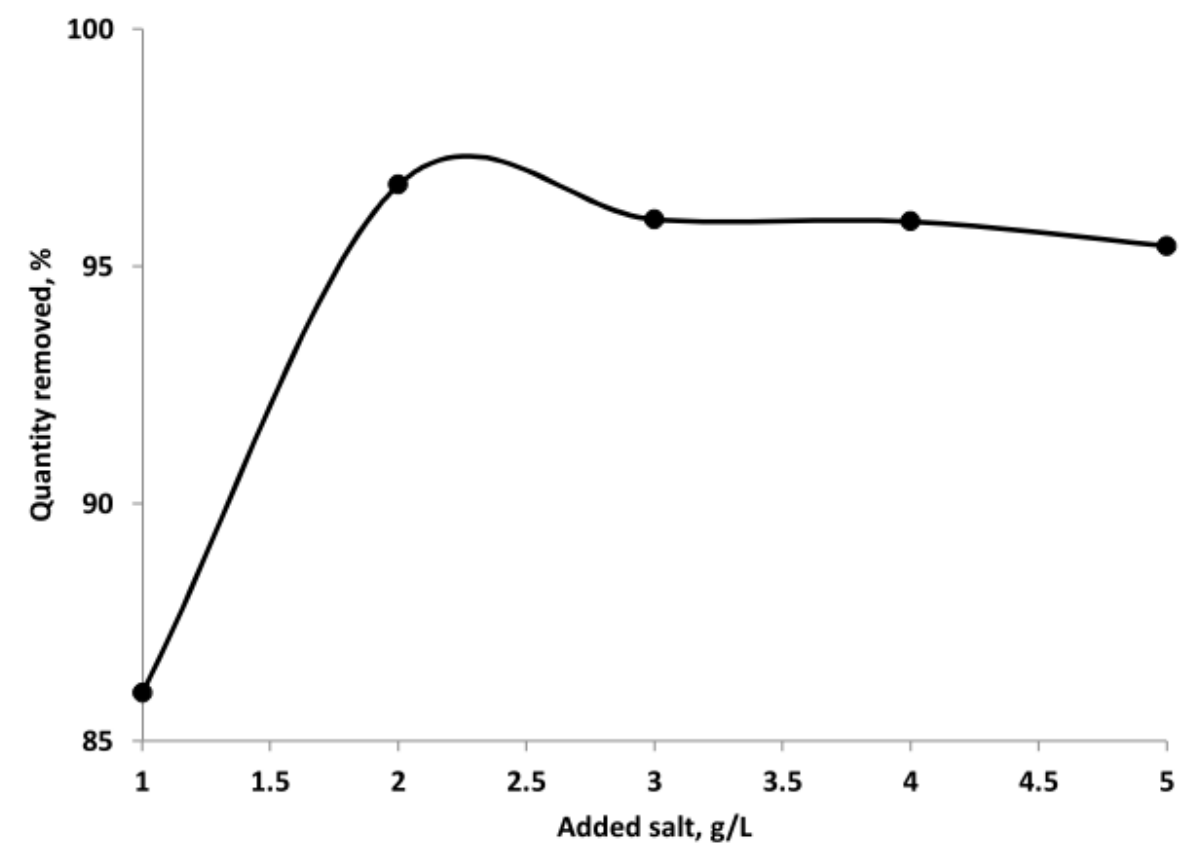

Figure. 5. Effect of electrolyte concentrations on colour removal ( $[$ ARS $]=50 \mathrm{mg} \mathrm{L}^{-1}, T=30^{\circ} \mathrm{C}, \mathrm{pH}=7, \mathrm{j}=21.5 \mathrm{~A} \mathrm{~m}^{-2}$ )

Effect of initial dye concentrations

The effect of initial dye concentration on the electrocoagulation removal of ARS is shown in Figure 6 for dye concentrations increasing from 25 to $100 \mathrm{mg} \mathrm{L}^{-1}$ at constant temperature of $30^{\circ} \mathrm{C}$, current density $21.5 \mathrm{~A} \mathrm{~m}^{-2}, \mathrm{pH} 7.0$ and electrolyte concentration maintained with $2 \mathrm{~g} \mathrm{~L}^{-1} \mathrm{NaCl}$. The process showed rapid removal in the first 10 minutes for all the concentrations studied. The efficiency of the process increases from 138 to $604.8 \mathrm{mg} \mathrm{g}^{-1}$ as the initial concentration increases from 25 to $100 \mathrm{mg} \mathrm{L}^{-1}$. As there is no significant difference in the amount coagulated after 20 minutes of the process, a steady-state approximation was assumed and a quasi-equilibrium situation was reached. The electrocoagulation curves were single, smooth, and continuous, leading to saturation. This is an indication of possible monolayer coverage on the surface of electrochemically generated coagulant $[18,37]$. 


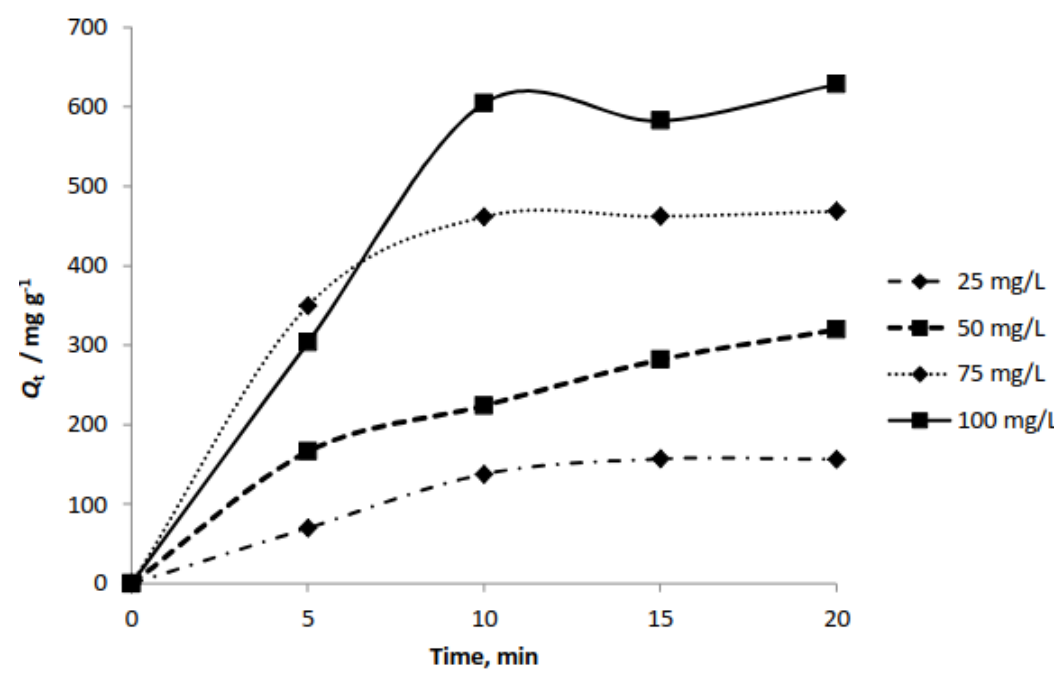

Figure 6. Effect of initial concentration on the electrocoagulation removal of ARS

$$
\left(T=30^{\circ} \mathrm{C}, \mathrm{pH}=7, \mathrm{j}=21.5 \mathrm{~A} \mathrm{~m}^{-2}[\mathrm{NaCl}]=2 \mathrm{gL}^{-1}\right)
$$

\section{Adsorption study}

Adsorption isotherms

The adsorption data obtained at different initial dye concentrations were fitted into six different isotherm models. The equations representing these models and the parameters are summarized in Table 1, the details of which have been explained elsewhere [38].

Table 1. Isotherm models used for the study of the EC removal of ARS

\begin{tabular}{lll}
\hline Isotherm name & Isotherm model & Parameters \\
\hline Langmuir & $Q_{\mathrm{e}}=\frac{Q_{\max } b C_{\mathrm{e}}}{1+b C_{\mathrm{e}}}$ & $Q_{\max }$ and $b$ \\
Freudlinch & $Q_{\mathrm{e}}=K_{\mathrm{F}} C^{1 / \mathrm{n}}$ & $K_{\mathrm{F}}$ and $n$, \\
Temkin & $Q_{\mathrm{e}}=\frac{R T}{B_{\mathrm{T}}} \ln \left(A_{\mathrm{T}} C_{\mathrm{e}}\right)$ & $A_{\mathrm{T}}$ and $B_{\mathrm{T}}$ \\
Dubinin- & & \\
Radushkevich & $Q_{\mathrm{e}}=Q_{\mathrm{s}} \exp -\frac{\left(R T \ln \left(1+\frac{1}{C_{\mathrm{e}}}\right)\right)^{2}}{2 E^{2}}$ & $Q_{\mathrm{s}}$ and $E$ \\
Redlich-Peterson & $Q_{\mathrm{e}}=\frac{Q_{\mathrm{o}} C_{\mathrm{e}}}{\left(1+K_{\mathrm{R}} C_{\mathrm{e}}^{\mathrm{g}}\right)}$ & \\
& $Q_{\mathrm{e}}=\frac{Q_{\mathrm{s}}\left(K_{\mathrm{s}} C_{\mathrm{e}}\right)^{\beta_{\mathrm{s}}}}{\left(1+\left(K_{\mathrm{s}} C_{\mathrm{e}}\right)^{\beta_{\mathrm{s}}}\right)}$ & $Q_{\mathrm{o}, K_{\mathrm{R}} \text { and } g}$ \\
Sip & $Q_{\mathrm{s}, K_{\mathrm{s}} \text { and } \beta_{\mathrm{s}}}$ \\
\hline
\end{tabular}

The adsorption data fitted well with all the isotherms as shown in Figure 7, however, Dubinin-Radushkevich and Sip's isotherms have the highest $R^{2}$ (Table 2). The $Q_{m}$ value of $785.31 \mathrm{mg} \mathrm{g}^{-1}$ obtained for the Langmuir isotherm model when compared with other isotherm $Q$ values shows that the Dubinin-Radushkevich and Sip's isotherm values are lower than the Langmuir isotherm (Table 2). The $1 / n$ value of $>1$ obtained for Freudlinch isotherm is also indication that the adsorption is favorable. 

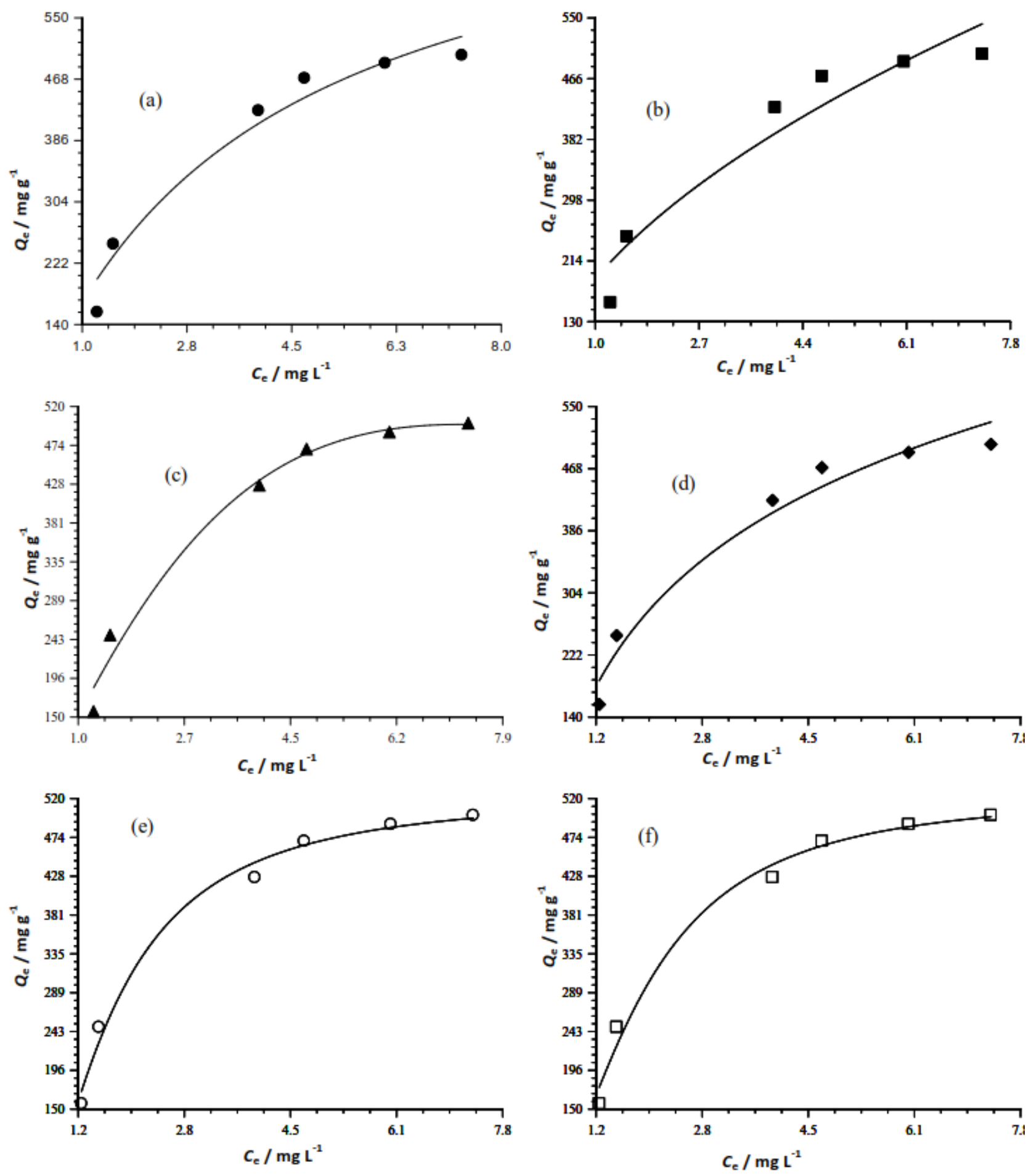

Figure 7. Least square plots of the (a) Langmuir, (b) Freundlich, (c) Redlich-Peterson, (d) Temkin (e) Dubinin-Radushkevich and (f) Sips isotherms for electrocoagulation of Alizarin S dye at $30^{\circ} \mathrm{C}$. 
Table 2. Isotherm parameters for electrocoagulation removal of Alizarin $S$

\begin{tabular}{lll}
\hline Isotherms & Parameters & \multicolumn{1}{c}{ Values } \\
\hline \multirow{4}{*}{ Langmuir } & $\mathrm{Q}_{\mathrm{max}} / \mathrm{mg} \mathrm{g}^{-1}$ & 785.31 \\
& $b / \mathrm{L} \mathrm{mg}^{-1}$ & 0.27 \\
& $R_{\mathrm{L}}$ & 0.055 \\
& $R^{2}$ & 0.996 \\
\hline \multirow{4}{*}{ Freudlinch } & $K_{\mathrm{F}} / \mathrm{mg} \mathrm{g}^{-1}\left(\mathrm{mg} \mathrm{L}^{-1}\right)^{-1 / \mathrm{n}}$ & 188.85 \\
& $n$ & 0.53 \\
& $R^{2}$ & 0.992 \\
\hline \multirow{4}{*}{ Tempkin } & $A_{\mathrm{T}} / \mathrm{L} \mathrm{g}^{-1}$ & 13.06 \\
& $B_{\mathrm{T}} / \mathrm{J} \mathrm{mol}^{-1} \mathrm{~g} \mathrm{mg}^{-1}$ & 2.12 \\
& $R^{2}$ & 0.997 \\
\hline \multirow{4}{*}{ Dubinin-Radushkevich } & $Q_{\mathrm{s}} / \mathrm{mg} \mathrm{g}^{-1}$ & 653.10 \\
& $E / \mathrm{kJ} \mathrm{mol}^{-1}$ & $5.65 \times 10^{-7}$ \\
& $R^{2}$ & 0.941 \\
\hline \multirow{4}{*}{ Redlich-Peterson } & $Q_{0} / \mathrm{mg} \mathrm{g}^{-1}$ & 4372.23 \\
& $K_{\mathrm{R}} /\left(\mathrm{mg}^{-1} \mathrm{~g}\right)^{1 / \mathrm{g}}$ & 0.036 \\
& $g$ & 1.80 \\
& $R^{2}$ & 0.998 \\
\hline \multirow{3}{*}{ Sips } & $Q_{\mathrm{s}} / \mathrm{mg} \mathrm{g}^{-1}$ & 524.63 \\
& $K_{\mathrm{s}} /\left(\mathrm{mg}^{-1} \mathrm{~L}\right)^{1 / \beta} \mathrm{s}$ & 0.57 \\
& $\beta_{\mathrm{s}}$ & 2.05 \\
& $R^{2}$ & 0.999 \\
\hline
\end{tabular}

\section{Electrocoagulation kinetics}

The plots of four different kinetic models used to explain the adsorption data are shown in Figure $8(a-d)$. The equations for these models are shown in Table 3 , details of which have explained elsewhere [38]. As shown in the figure, pseudo-first-order kinetic models fitted well with experimental data when compared with other models the $R^{2}$ value of the model also confirmed this (Table 4). The rate constant from all the models increases with initial dye concentration up to $75 \mathrm{mg} \mathrm{L}^{-1}$ before decreasing at $100 \mathrm{mg} \mathrm{L}^{-1}$. This shows that at higher initial concentration the electrostatic interaction decreases at the site, thereby lowering the adsorption rate. The behaviour of Elovich constant shows that the process of adsorption is more than one mechanism.

Table 3: Kinetic models for the EC process

\begin{tabular}{lll}
\hline Isotherm name & Isotherm model & Parameters \\
\hline Pseudo First Order & $Q_{\mathrm{t}}=Q_{\mathrm{e}}\left(1-e^{\left(-k_{1} t\right)}\right)$ & $Q_{\mathrm{e}}$ and $k_{1}$ \\
\hline Pseudo Secon Order & $Q_{\mathrm{t}}=\frac{Q_{\mathrm{e}}^{2} k_{2} t}{\left(1+Q_{\mathrm{e}} k_{2} t\right)}$ & $Q_{\mathrm{e}}$ and $k_{2}$ \\
\hline Elovich & $Q_{\mathrm{t}}=\frac{1}{\beta} \ln (\alpha \beta t)$ & $\alpha$ and $\beta$ \\
\hline Avramin & $Q_{\mathrm{t}}=Q_{\mathrm{e}}\left(1-e^{-k_{\mathrm{av}} \mathrm{t}_{\mathrm{av}}}\right)$ & $k_{a v}$, and $n_{a v}$ \\
\hline Intraparticulate model & $Q_{\mathrm{t}}=K_{\mathrm{id}} t^{0.5}+C_{\mathrm{i}}$ & $K_{i d}$ and $C_{i}$ \\
\hline
\end{tabular}



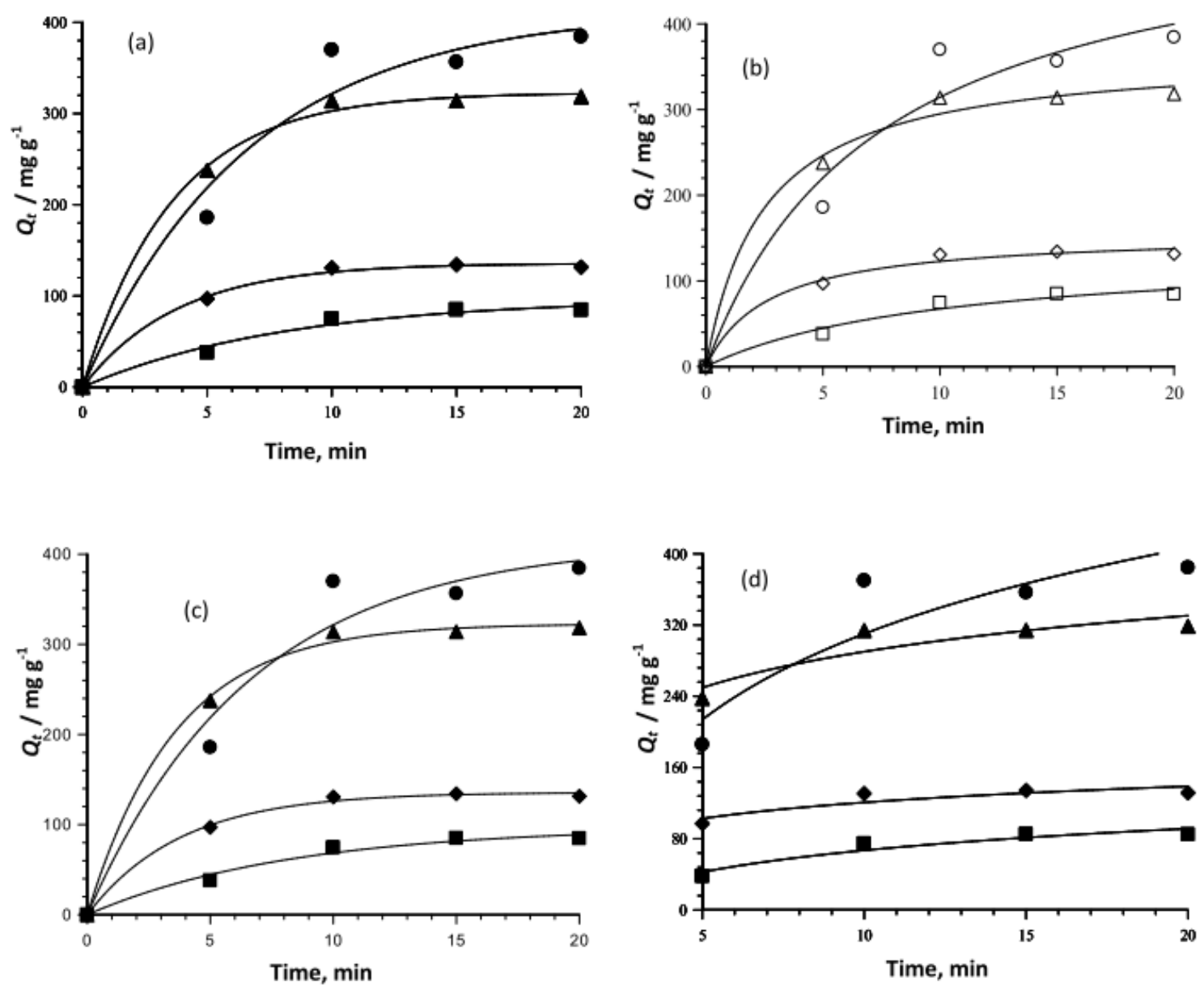

Figure 8. Least square plots of (a) pseudo-first-order, (b) pseudo-second-order, (c) Avramin and (d) Elovich kinetic models for Alizarin S dye electrocoagulation at $30^{\circ} \mathrm{C}$.

Table 4. Comparison of kinetic model constant values for Alizarin Red S removal by electrocoagulation

\begin{tabular}{|c|c|c|c|c|c|}
\hline & $C_{0} / \mathrm{mg} \mathrm{L}^{-1}$ & 25.00 & 50.00 & 75.00 & 100.00 \\
\hline & $Q_{\text {exp }} / \mathrm{mg} \mathrm{g}^{-1}$ & 74.52 & 130.75 & 313.80 & 369.92 \\
\hline \multirow{4}{*}{ First order } & $\mathrm{Q}_{\mathrm{e} \text { cal }} / \mathrm{mg} \mathrm{g}^{-1}$ & 97.30 & 135.75 & 322.81 & 413.23 \\
\hline & $k_{1} / \min ^{-1}$ & 0.12 & 0.26 & 0.28 & 0.15 \\
\hline & $R^{2}$ & 0.995 & 0.999 & 0.997 & 0.992 \\
\hline & SSE, \% & 6.11 & 0.76 & 0.57 & 2.34 \\
\hline \multirow{4}{*}{ Second order } & $\mathrm{Q}_{\mathrm{e} \text { cal }} / \mathrm{mg} \mathrm{g}^{-1}$ & 136.04 & 155.88 & 367.39 & 548.90 \\
\hline & $k_{2} 10^{-3} / \mathrm{g} \mathrm{mg}^{-1} \mathrm{~min}^{-1}$ & 0.7204 & 2.3817 & 1.1079 & 0.2444 \\
\hline & $R^{2}$ & 0.993 & 0.998 & 0.998 & 0.989 \\
\hline & SSE, $\%$ & 16.51 & 3.84 & 3.42 & 9.68 \\
\hline \multirow{5}{*}{ Avramin } & $Q_{\text {e cal }} / \mathrm{mg} \mathrm{g}^{-1}$ & 97.30 & 135.75 & 322.81 & 413.23 \\
\hline & $k_{\mathrm{av}} / \min ^{-1}$ & 0.35 & 0.51 & 0.53 & 0.39 \\
\hline & $n_{\mathrm{av}}$ & 0.35 & 0.51 & 0.53 & 0.39 \\
\hline & SSE, $\%$ & 6.11 & 0.76 & 0.57 & 2.34 \\
\hline & $R^{2}$ & 0.995 & 0.999 & 0.999 & 0.992 \\
\hline \multirow{4}{*}{ Elovich } & $\beta / \mathrm{g} \mathrm{mg}^{-1}$ & 0.03 & 0.04 & 0.02 & 0.01 \\
\hline & $\alpha / \mathrm{mg}\left(\mathrm{g} \mathrm{min}^{-1}\right.$ & 23.52 & 267.45 & 840.16 & 129.21 \\
\hline & $R^{2}$ & 0.993 & 0.997 & 0.998 & 0.989 \\
\hline & SSE, $\%$ & 13.69 & 20.91 & 33.55 & 13.01 \\
\hline
\end{tabular}


Adsorption mechanism

The mechanism of adsorption was investigated by subjecting the data to intra-particulate diffusion model. The plots are shown in Figure 9. The plots are not linear over the whole time range but rather they exhibit multi-linearity revealing the existence of two successive adsorption steps. The first stage is faster than the second, and it is attributed to the external surface adsorption referred to as the boundary layer diffusion. Thereafter, the second linear part is attributed to the intraparticle diffusion stage; this stage is the rate controlling step. Table 5 shows the intra-particle model constants for the electrocoagulation removal of ARS dye. The $K_{\text {di }}$ values were found to increase from first stage of adsorption toward the second stage. The increase in dye concentration results in an increase in the driving force thereby increasing the dye diffusion rate.

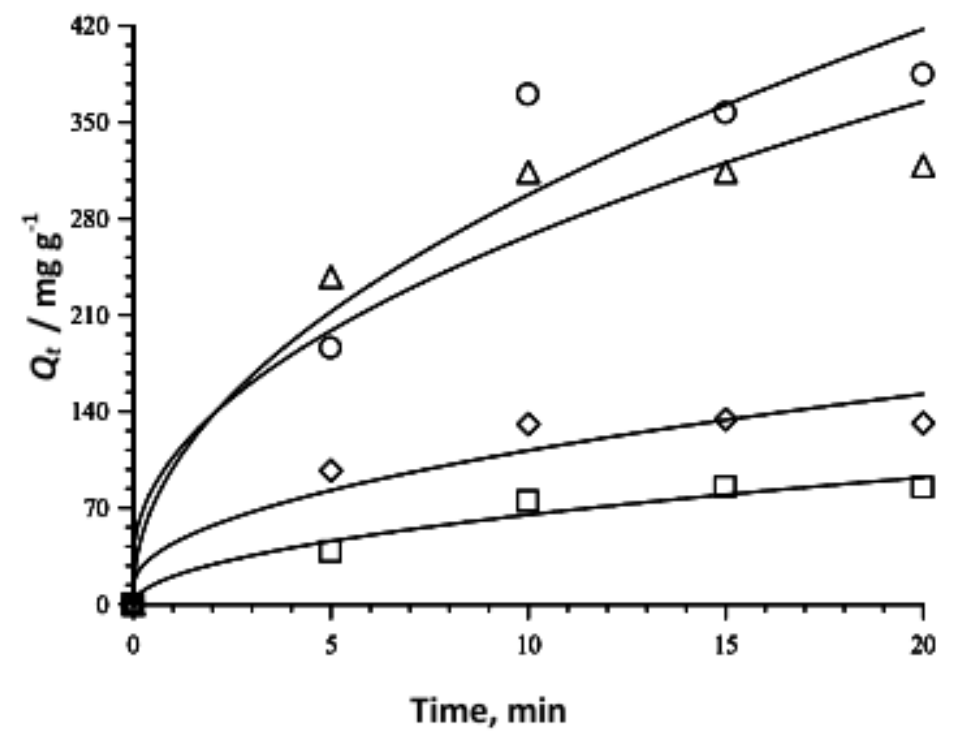

Figure 9. Intraparticulate diffusion model plots for Alizarin $\mathrm{S}$ dye electrocoagulation at $30^{\circ} \mathrm{C}$.

Table 5. Intra-particle diffusion model for the electrocoagulation removal of Alizarin S

\begin{tabular}{lcccc}
\hline$C_{\mathrm{o}} / \mathrm{mg} \mathrm{L}^{-1}$ & 25 & 50 & 75 & 100 \\
\hline$K_{\mathrm{d} 1} / \mathrm{mg} \mathrm{g}^{-1} \mathrm{~min}^{-0.5}$ & 22.34 & 41.72 & 100.53 & 110.72 \\
\hline$K_{\mathrm{d} 2} / \mathrm{mg} \mathrm{g}^{-1} \mathrm{~min}^{-0.5}$ & 7.92 & 0.68 & 3.39 & 10.23 \\
\hline$C_{1}$ & -2.73 & 0.85 & 2.91 & -14.00 \\
\hline$C_{2}$ & 50.97 & 129.52 & 302.38 & 331.09 \\
\hline$R_{1}{ }^{2}$ & 0.980 & 0.999 & 0.999 & 0.979 \\
\hline$R_{2}{ }^{2}$ & 0.999 & 0.999 & 0.999 & 0.999 \\
\hline
\end{tabular}

Thermodynamic parameters

Figure 10 shows that the rate constants vary with temperature according to Equation 9 . The activation energy $\left(3.55 \mathrm{~kJ} \mathrm{~mol}^{-1}\right)$ was obtained from the slope of the fitted equation. The free energy change, $\Delta G$ is obtained from Equations 10 and 11 according to the van't Hoff linear plots of In $K_{\mathrm{d}}$ versus $1 / T$ plot in Figure 10 ( $\mathrm{a}$ and $\mathrm{b}$ ). The thermodynamic parameters are presented in Table 6. It was found that the negative value of $\Delta G$ indicates the spontaneous nature of adsorption. Positive value of enthalpy change indicates that the adsorption process is endothermic in nature, and the negative value of change in internal energy $(\Delta G)$ shows the spontaneous adsorption of ARS on the coagulant. Positive values of entropy change show the increased randomness of the solution interface during the adsorption process (Table 6). 
a

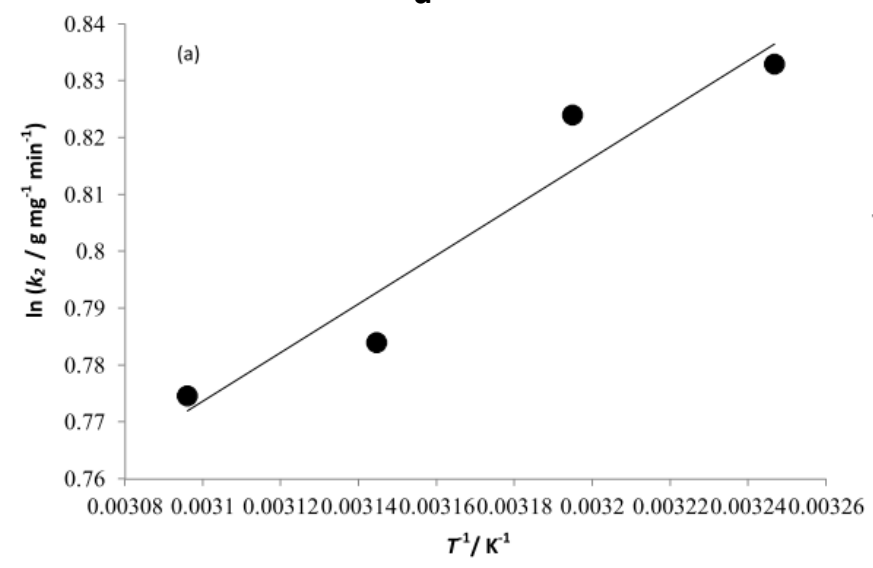

b

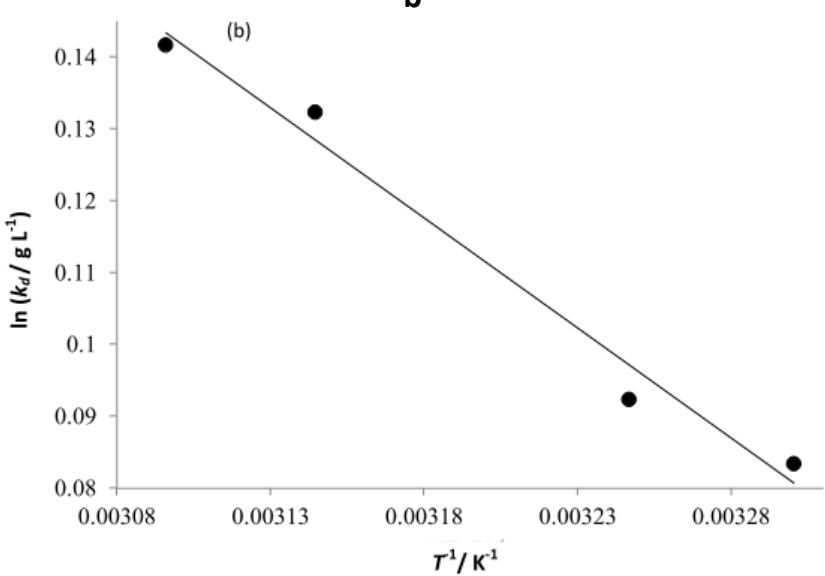

Figure 10. Thermodynamic plot (a) In $\mathrm{k}_{2}$ and $1 / T$ and $(b)$ In $\mathrm{K}_{d}$ and $1 / \mathrm{T}$ for the removal of Alizarin $S$ dye by electrocoagulation.

Table 6. Thermodynamic parameters for the removal of Alizarin S

\begin{tabular}{ccccccc}
\hline$T / \mathrm{K}$ & $K$ & $\Delta G / \mathrm{kJ} \mathrm{mol}^{-1}$ & $E_{\mathrm{a}} / \mathrm{kJ} \mathrm{mol}^{-1}$ & $\Delta S / \mathrm{bJ} \mathrm{mol}$ & $\Delta H / \mathrm{kJ} \mathrm{mol}^{-1}$ & $R^{2}$ \\
\hline 303 & 1.0870 & -5.301 & 3.55 & 9.083 & 2.549 & 0.981 \\
\hline 308 & 1.0967 & -5.346 & & & & \\
\hline 318 & 1.1415 & -5.437 & & & & \\
\hline 323 & 1.1522 & -5.483 & & & & \\
\hline
\end{tabular}

FT-IR Studies of the dye solution before and after electrocoagulation

Figure 11 presents the FT-IR spectrum of the dye solution before and after the process. Before the electrocoagulation the spectrum shows several peaks; sharp and strong peak at $3440.8 \mathrm{~cm}^{-1}$ could be assigned to $-\mathrm{OH}$ stretching on the dye molecule while, that at $2821 \mathrm{~cm}^{-1}$ is due to $-\mathrm{CH}-$. Peaks at 1593 and $1350 \mathrm{~cm}^{-1}$ are due to the aromatic $\mathrm{C}=\mathrm{C}$ stretching. After electrocoagulation, the extra structure noted such as that at $3840 \mathrm{~cm}^{-1}$ may be assigned to the $(\mathrm{O}-\mathrm{H})$ stretching vibration in the $\mathrm{Al}(\mathrm{OH})_{3}$ structures.

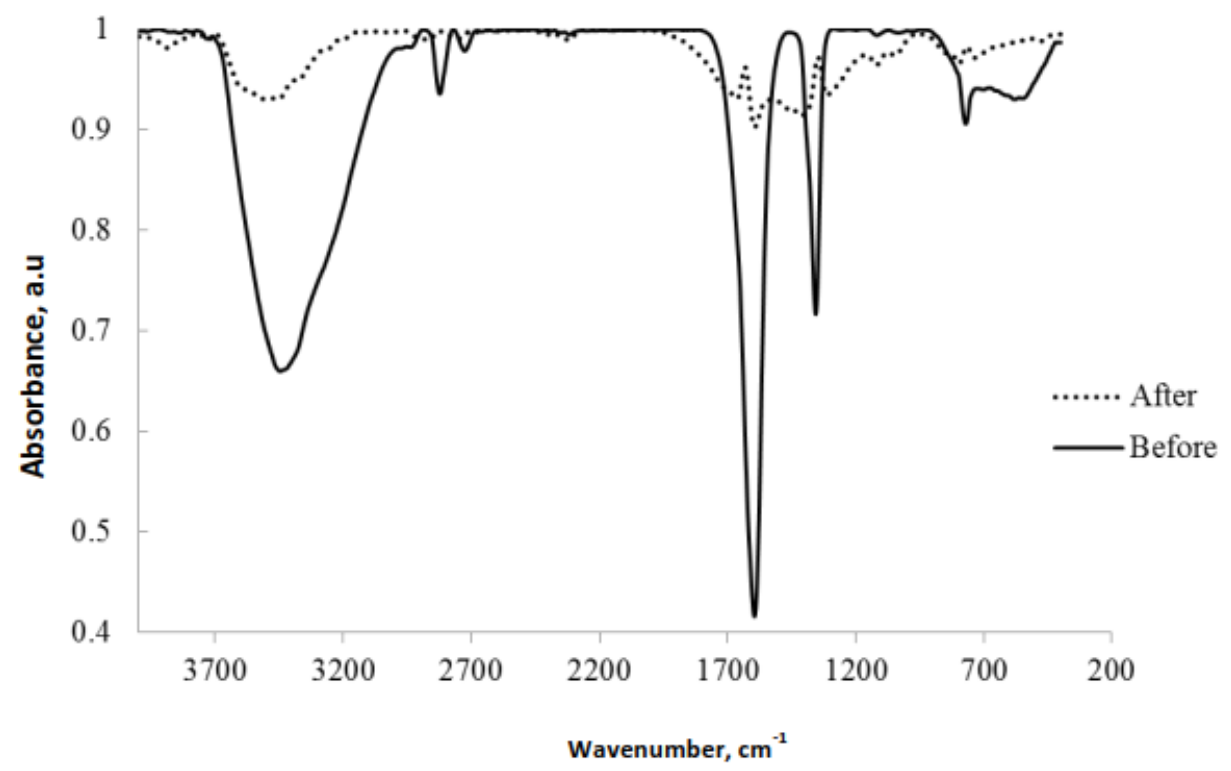

Figure 12. FTIR of the solution of Alizarin Red $S$ dye before and after removal 


\section{Conclusions}

This study revealed the feasibility of the use of electrocoagulation techniques for removing Alizarin Red $\mathrm{S}$ from its aqueous solution in a process. The process depends on numerous factors such as: current density, solution $\mathrm{pH}$, temperature, initial dye concentration and contact time. The percentage removal of the dye increased with $\mathrm{pH}$ up to $\mathrm{pH} 7$, also contact time and current density increase influence the removal positively. Equilibrium data fitted very well in the Langmuir isotherm equation, confirming the monolayer adsorption capacity of $785.31 \mathrm{mg} \mathrm{g}^{-1}$ at $303 \mathrm{~K}$. The kinetics of the process is best explained using a pseudo first order kinetics model, with higher $R^{2}$ (Table 4). Intra-particle diffusion was not the sole rate controlling factor. The thermodynamics parameters obtained indicates that the process is spontaneous endothermic nature of the process. Therefore, the present findings suggested a better performance of electrocoagulation with Al electrode as an inexpensive method for the removal of ARS aqueous solutions.

Acknowledgements: The financial support in the form of grants from CSIR, for twelve months TWAS-CSIR Postdoctoral Fellowship, FR number: 3240275035, awarded to Abideen Idowu Adeogun that enables this work to be carried out. Also he is thankful to the authority of the Federal University of Agriculture, Abeokuta, Nigeria for granting the study leave to honour the fellowship.

\section{References}

[1] G. Crini, Bioresources Technology 97 (2006) 1061-1085.

[2] S. Rajgopalan, Pollution Management in Industries Trivedy RK (Eds.) Environmental Publications, Karad., India (1995) p. 44.

[3] T. Routh, Journal of Environmental Protection 20(2) (1998) 115-123.

[4] D.W.Kolpin, E.T. Furlong, M.T. Meyer, E.M. Thurman S.D. Zaugg, L.B. Barber, H.T. Buxton, Environmental Science and Technology 36(6) (1999-2000) 1202-1211.

[5] M. Ali, T.R. Sreekrishnan, Advance in Environmental Research 5 (2001) 175-196.

[6] Q.Y. Sun, L.Z. Yang, Water Research 37 (2003) 1535-1544.

[7] R.A. Shawabkeh, M.F. Tutunji, Applied Clay Science 24(1-2) (2003) 111-120.

[8] G.H. Lin, D.J. Brusick, Journal of Applied Toxicology 12(4) (1992) 267-274.

[9] P. Zucca, C. Vinci, F. Sollai, A. Rescigno, E. Sanjust, Journal of Molecular Catalysis A: Chemical 288 (2008) 97-102.

[10] P.A. Carneiro, M.E. Osugi, C.S. Fugivar, N. Boralle, M. Furlan, M.V. Zanoni, Chemosphere 59(3) (2005) 431-439.

[11] M. Panizza, P.A. Michaud, G. Cerisola, C. Comninellis, Electrochemistry Communications 3 (2001) 336-339.

[12] Z.X. Wang, X.C. Xu, Z. Gong, F.Y. Yang, Journal of Hazardous Materials 78(1) (2012) 235236.

[13] A. Aleboyeh, N. Daneshvar, M. B. Kasiri, Chemical Engineering Process 47 (2008) 827-832.

[14] F. Ghanbari, M. Moradi, A. Eslami, M.M. Emamjomeh, Environmental Process 1 (2014) 447457.

[15] M.O. Nkiko, A.I. Adeogun, N.A.A. Babarinde, O. J. Sharaibi, Journal of Water Reuse and Desalination 3(3) (2013) 239-248.

[16] B. Merzouk, M. Yakoubi, I. Zongo, J.P. Leclerc, G. Paternotte, S. Pontvianne, F. Lapicque Desalination 275(1-3) (2011) 181-186.

[17] J. Zolgharnein, M. Bagtash and N. Asanjarani, Journal of Environmental and Chemical Engineering 2 (2014) 988-1000.

[18] T. Moriguchi, K. Yano, S. Nakagawa, F. Kaji, Journal of Colloidal Interface Science 260 (2003) 19-25. 
[19] M. Ghaedi, A. Hassanzadeh, S.N. Kokhdan, Journal of Chemical Engineering and Data 56 (2011) 2511-2520.

[20] C. Saez, M. Panizza, M.A. Rodrigo, G. Cerisola, Journal of Chemical Technology and Biotechnology 82(6) (2007) 575 - 581.

[21] M. Panizza, M.A. Oturan, Electrochimica Acta 56 (2011) $7084-7087$.

[22] F. Yi, S. Chen, C. Yuan Journal of Hazardous Materials B157 (2008) 78-87.

[23] M. Panizzan, G. Cerisola, Water Research 43 (2009) 339.

[24] N. Daneshvar, A. Oladegaragoze, N. Djafarzadeh, Journal of Hazardous Materials B129 (2006) 116-122.

[25] I. Langmuir, Journal of American Chemical Society 40 (1918) 1361-1403.

[26] H.M.F. Freundlich, Journal of Physical Chemistry 57 (1906) 385-471.

[27] M.I. Tempkin, V. Pyzhev, Acta Physica Chimca USSR 12 (1940) 327-356.

[28] M.M. Dubinina, L.V. Radushkevich, Izvestiya Akademii nauk, fizicheskoy khimii sektsii USSR 55 (1947) 331-333.

[29] R. Sips, Journal of Chemical Physics 16 (1948) 490-495.

[30] O. Redlich, D.L. Peterson, Journal of Physical Chemistry 63 (1959) 1024-1026.

[31] T.S Aniruldhan, P.G. Radhakrishnan, Journal of Chemical Thermodynamics 40 (2008) 702709.

[32] N. Daneshvar, A. Oladegaragoze, N. Djafarzadeh Journal of Hazardous Materials B129 (2006) 116-122.

[33] N. Daneshvar, D. Salari, A. R. Khataee, Journal of Photochemistry and Photobiology A 157 (2003) 111-116.

[34] M.Y.A. Mollah, P. Morkovsky, J.A.G. Gomes, M. Kesmez, J. Parga, D.L. Cocke, Journal of Hazardous Materials B 114 (2004) 199-210.

[35] M. Bayramoglu, M. Kobya, O. Can, T.M. Sozbir, Separation Purification Technology 37 (2004) 117-125.

[36] M. Kobya, E. Demirbas, A. Dedeli, M.T. Sensoy, Journal Hazardous Material 173 (2010) 326334.

[37] P. Saha, S.K. Sanyal, Desalination, 59 (2010) 131-139.

[38] A.I. Adeogun, B.R. Balakrishnan, Applied Nanoscience (2015) Doi: 10.1007/s13204-0150484-9.

(C) 2016 by the authors; licensee IAPC, Zagreb, Croatia. This article is an open-access article distributed under the terms and conditions of the Creative Commons Attribution license (http://creativecommons.org/licenses/by/4.0/) 